Bangladesh Agron. J. 2015, 18(2): 45-52

\title{
IMPACT OF SOWING DATE INDUCED TEMPERATURE AND MANAGEMENT PRACTICES ON DEVELOPMENT EVENTS AND YIELD OF MUSTARD
}

\author{
M.S.A. Khan and M.A. Aziz \\ Agronomy Division, Bangladesh Agricultural Research Institute, Joydebpur, Gazipur-1701, Bangladesh \\ Corresponding author: shawquatshahadat@yahoo.com
}

Key words: Brassica spp., temperature, growing degree days, productivity

\begin{abstract}
The experiment was conducted at the research field of the Agronomy Division, Bangladesh Agricultural Research Institute (BARI), Joydebpur, Gazipur, during rabi season of 2014-2015 to find out the relationship between different development events of mustard crop and sowing dates induced temperature as well as to minimize the yield reduction of the crop by adopting appropriate management practices. The mustard var. BARI Sarisha-15 was sown on 06, 25 November and 14 December 2014. Crop accumulated lower growing degree days (GDD) i.e., 72.15, 521.10 and 1070 to $1154{ }^{\circ} \mathrm{C}$ were observed for the events of emergence, $50 \%$ flowering and maturity on 14 December sowing. Late sown plants took minimum time from flowering to maturity ( 36 days) due to increased temperature and high variability in both maximum and minimum temperature. The highest seed yield (1569 $\left.\mathrm{kg} \mathrm{ha}^{-1}\right)$ was recorded from 06 November sowing with high management practices while the lowest seed yield $\left(435 \mathrm{~kg} \mathrm{ha}^{-1}\right)$ from 14 December sowing with low management practices. At high management practices the crop yielded $1183 \mathrm{~kg} \mathrm{ha}^{-1}$ at 14 December sowing. Yield reduction at late sowing condition was reduced to some extent with high management practices. The seed yield reductions at 14 December sowing as compared to high management practices at 06 November sowing were 72,43 and $25 \%$ under low, medium and high management, respectively.
\end{abstract}

\section{Introduction}

Agriculture is one of the most vulnerable sectors to the climate change impact in Bangladesh. Climate change refers to any change in climate over time, whether due to natural variability or as a result of human activity (IPCC, 2007). IPCC reported that the area averaged annual mean warming will be around $3^{\circ} \mathrm{C}$ in the decade of $2050 \mathrm{~s}$ and around $5^{\circ} \mathrm{C}$ in the decade of 2080 s over land part of Asiatic region. This change may alter the geographical distribution and growing season of agricultural crops (Porter, 2005). Among the different climatic factors temperature adversely affects crops especially winter crops in Bangladesh. Mustard is one of the major oil seed crops in Bangladesh. Its grows in temperature between $10^{\circ} \mathrm{C}$ and $30^{\circ} \mathrm{C}$, but the optimum temperature for growth of Brassica napus and Brassica rapa species is about $20^{\circ} \mathrm{C}$ (Thomas, 1984). In Bangladesh, it is grown under different environmental situations such as timely or late sown, with or without fertilizer and rainfed or irrigated conditions. It is mostly grown after T. aman rice in rice based cropping pattern. Since, mustard is grown in winter season and winter is becoming shorter due to climate change, the growth of the crop may be affected by the climate change. High temperature in Brassica enhanced plant development and caused flower abortion with significant loss in seed yield (Rao et al., 1992). Most of the cultivated soils have growth limiting problems associated with mineral-nutrient deficiencies (Cakmak, 2002). Nitrogen fertilization has been reported to mitigate the adverse effects of abiotic stress (Waraich et al., 2011). On the other hand potassium plays a crucial role in survival of crop plants under 
Khan et al.

environmental stress conditions (Munns, 2005). However, it is necessary to determine the relationship between different development events of the crop and the prevailing temperature for the development of appropriate management option to minimize the yield reduction. Therefore, this study was done to analyze the impacts of sowing date induced temperature and management practices on development events and yield of mustard.

\section{Materials and Methods}

The experiment was conducted at the research field of the Agronomy Division, Bangladesh Agricultural Research Institute (BARI), Joydebpur, Gazipur, during rabi season of 20142015. The location of the experimental site is situated at about $23^{0} 59^{\prime}$ north latitude, $90^{\circ} 24^{\prime}$ east longitudes and an altitude of $8.4 \mathrm{~m}$ above sea level. The soil was silty clay in texture with $\mathrm{pH}$ of 6.5. The experiment was laid out in a split-plot design with three replications. The sowing dates were: i. 06 November (timely), ii. 25 November (late) and iii. 14 December (too late); while the management practices were: i. Low: 60-15-30-10 kg NPKS/ha, no irrigation, no weeding, no pesticide. ii. Medium: 80-25-60-20 kg NPKS/ha, one weeding at $21 \mathrm{DAE}$, two irrigations at rosset and flowering stages \& spraying pesticides, and iii. High: 120-35-90-30 $\mathrm{kg} \mathrm{NPKS} / \mathrm{ha}$, one weeding at $21 \mathrm{DAE}$, two irrigations at rosset and flowering stages, \& spraying pesticides. The sowing dates were assigned in the main plots and management practices in sub-plots. The mustard var. BARI Sarisha-15 was used as a test crop. Seeds were sown in lines with maintaining $30 \mathrm{~cm}$ row to row spacing. Half of urea and full doses of other fertilizers were applied at the time of final land preparation. The remaining half of urea was top dressed at vegetative and flowering stage followed by irrigation. In case of low management, all fertilizers were applied at the time of final land preparation. Insecticide and fungicide were sprayed in the respective treatment plots. Admire 200SL @ $1 \mathrm{ml} /$ liter of water was sprayed at 20 and 35 DAE to control Jassids and white flies. Rovral-50 WP @ 2 g/liter of water was sprayed at 30 and $45 \mathrm{DAE}$ to control Alternaria diseases. Daily temperatures were recorded for computing required growing degree days (GDD) for different stages. GDD were computed by using daily normal maximum air temperature, minimum air temperature, mean air temperature and considering base temperature of $5^{\circ} \mathrm{C}$ for mustard (Singh et al., 2014). The sum of degree days for the completion of different development stage of mustard were obtained by using the following formula (Kumar et al., 2008); Accumulated GDD (ㄷ C day) $=$ Summation (Daily mean air temperature in $\circ \mathrm{C}-$ Base temperature of mustard). At flowering stage, plant samples were collected from an area of one square meter of all treatments and different plant parts of the collected samples were separated and then oven dried at $70{ }^{\circ} \mathrm{C}$ for 4 days to measure the dry weight. At harvest, yield contributing characters were recorded from selected five plants and yield data were recorded by harvesting one square meter area. Data were analyzed by MSTAT-C and means were compared using Least Significant Difference (LSD).

\section{Results and Discussion}

\section{Days for development events}

Total number of days required for different development events of mustard grown under different sowing dates and management practices are presented in Table 1. All developmental events varied due to variations in sowing dates and management practices. The events of emergence, first flowering and $50 \%$ flowering did not differ by management practices but differed by sowing dates. The crop sowm on 25 November took maximum days (6) for emergence and the minimum days (4 days) on 06 November 2014 December sowing took maximum days (34) for first flowering and 50\% flowering (38 days), whereas crop 
Impact of Sowing Date Induced Temperature and Management

sown on 06 November took minimum days (29) for first flowering and 50\% flowering (35 days). The days for maturity varied by sowing date and management practices. Sown on 06 November took maximum days (80 to 83), while that of 14 December took the minimum days for maturity (74 to 78 ). Crop with low management practices took minimum days for maturity while medium and high management practices took maximum days. The minimum day (74) for maturity was found in plants of 14 December sowing at low management practices. Plants developed from both the medium and high management practices took similar days for maturity at each sowing date.

Table 1. Total number of days required for different developmental events of mustard grown at different sowing dates under different management practices

\begin{tabular}{c|l|c|c|c|c}
\hline \multicolumn{2}{c|}{ Treatments } & \multicolumn{4}{c}{ Developmental events } \\
\hline $\begin{array}{c}\text { Sowing } \\
\text { dates }\end{array}$ & Management & Emergence & First flowering & $\begin{array}{c}50 \% \\
\text { Flowering }\end{array}$ & Maturity \\
\hline 06 Nov. & Low & 4 & 29 & 35 & 80 \\
& Medium & 4 & 29 & 35 & 83 \\
25 Nov. & High & 4 & 29 & 35 & 83 \\
& Low & 6 & 33 & 39 & 79 \\
& Medium & 6 & 33 & 39 & 83 \\
14 Dec. & High & 6 & 33 & 39 & 83 \\
& Low & 5 & 34 & 38 & 74 \\
& Medium & 5 & 34 & 38 & 78 \\
& High & 5 & 34 & 38 & 78 \\
\hline
\end{tabular}

Temperatures and development events

Both maximum and minimum temperatures were higher at 06 November sowing that reduced the number of days for emergence and first flowering (Table 2). The higher maximum temperatures for emergence and flowering were $33.0 \pm 0.94{ }^{\circ} \mathrm{C}$ and $29.0 \pm 1.80$ ${ }^{\circ} \mathrm{C}$ and minimum were $21.9 \pm 2.35^{\circ} \mathrm{C}$ and $16.1 \pm 2.20^{\circ} \mathrm{C}$, respectively.

Table 2. Prevailing temperature during different development events of mustard grown at different sowing dates under different management practices during rabi season, 2014-2015

\begin{tabular}{l|c|c|c|c|c}
\hline Developmental & Sowing dates & \multicolumn{2}{|c|}{ Maximum temperature $\left({ }^{\circ} \mathrm{C}\right)$} & \multicolumn{2}{c}{ Minimum temperature $\left({ }^{\circ} \mathrm{C}\right)$} \\
\cline { 3 - 6 } events & & Range & Mean $\pm \mathrm{SD}$ & Range & Mean $\pm \mathrm{SD}$ \\
\hline Sowing to & 06 November & $32.2-34.0$ & $33.0 \pm 0.94$ & $19.5-25.0$ & $21.9 \pm 2.35$ \\
emergence & 25 November & $26.5-28.8$ & $27.5 \pm 0.72$ & $13.6-15.0$ & $14.3 \pm 0.57$ \\
& 14 December & $20.7-27.8$ & $24.4 \pm 2.82$ & $13.0-17.0$ & $14.5 \pm 2.06$ \\
Emergence to & 06 November & $26.5-34.0$ & $29.0 \pm 1.80$ & $13.6-21.2$ & $16.1 \pm 2.20$ \\
first flowering & 25 November & $15.6-28.8$ & $24.5 \pm 3.54$ & $11.0-17.0$ & $13.7 \pm 1.94$ \\
& 14 December & $15.6-30.0$ & $24.8 \pm 3.26$ & $9.8-19.7$ & $13.0 \pm 3.07$ \\
First flowering & 06 November & $22.3-28.8$ & $24.9 \pm 2.98$ & $12.5-17.0$ & $15.0 \pm 1.96$ \\
to 50\% & 25 November & $21.2-29.4$ & $24.5 \pm 2.45$ & $11.0-19.2$ & $12.1 \pm 1.99$ \\
flowering & 14 December & $15.5-26.7$ & $19.4 \pm 5.09$ & $12.0-15.3$ & $13.0 \pm 1.54$ \\
$50 \%$ flowering & 06 November & $15.5-30.0$ & $24.3 \pm 3.52$ & $9.8-19.7$ & $13.2 \pm 2.65$ \\
to maturity & 25 November & $15.5-30.0$ & $29.6 \pm 2.39$ & $9.8-19.7$ & $15.7 \pm 3.05$ \\
& 14 December & $20.5-33.0$ & $27.6 \pm 2.45$ & $10.0-21.0$ & $14.1 \pm 3.28$ \\
\hline
\end{tabular}

Due to high variability in maximum temperature (range: $15.5-26.7^{\circ} \mathrm{C}$, mean: $19.4 \pm 5.09$ $\left.{ }^{\circ} \mathrm{C}\right) 14$ December sowing took minimum days from first flowering to $50 \%$ flowering. From $50 \%$ flowering to maturity, temperatures were lower at 06 November sowing (max.) that increased the number of days for maturity. Average maximum and minimum temperatures for $50 \%$ flowering to maturity were higher in 25 November sowing than 14 December 
Khan et al.

sowing. The maximum and minimum temperatures ranged from $15.5-30.0{ }^{\circ} \mathrm{C}$ and $9.8-$ $19.7^{\circ} \mathrm{C}$ for 25 November sowing and $20.5-33.0^{\circ} \mathrm{C}$ and $10.0-21.0^{\circ} \mathrm{C} 14$ December sowing, respectively. The high variability in both maximum and minimum temperature induced by 14 December sowing enhanced maturity of the mustard crop (Fig. 1).

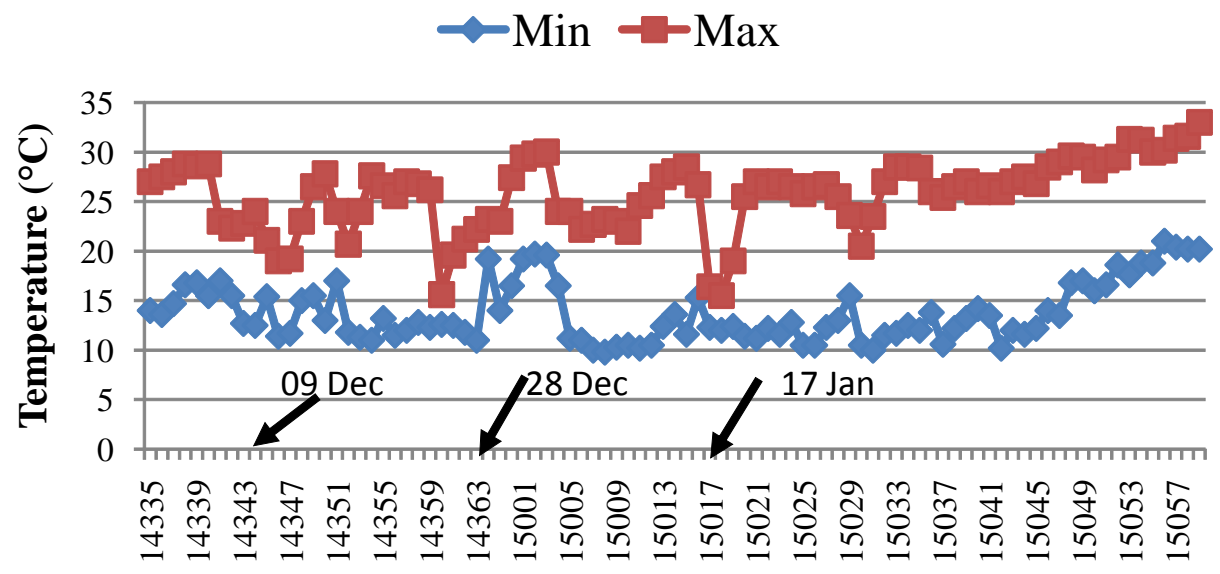

Julian days

Fig. 1. Prevailing temperature from flowering to maturity of mustard grown at different sowing dates (arrows indicate starting of flowering for different sowing dates).

\section{Growing Degree Days for development events}

The accumulated growing degree days (GDD) required for different development events of mustard varied under different sowing dates and management practices (Table 3). Among the different dates of sowing, 06 November sowing accumulated maximum GDD of 89.70, 591.35 and $665.25{ }^{\circ} \mathrm{C}$ for the events of emergence, first flowering and $50 \%$ flowering, respectively. The minimum accumulated GDD of 72.15 and $521.10^{\circ} \mathrm{C}$ were observed for the events of emergence and $50 \%$ flowering at 14 December sowing, respectively. For maturity stage of the mustard plants, the maximum accumulated GDD $\left(1284.35\right.$ to $\left.1323.65^{\circ} \mathrm{C}\right)$ was recorded on 06 November sowing and the minimum $\left(1070.20\right.$ to $1154.20^{\circ} \mathrm{C}$ ) on 14 December sowing. The GDD also varied under different management practices of mustard at maturity. The minimum GDD was observed for maturity under low management practices at all dates of sowing.

\section{Total dry matter}

Total dry matter production at flowering and their distribution in different plant parts under different sowing dates and management practices (Fig. 2). The highest total dry matter (93 $\mathrm{g} \mathrm{m}^{-2}$ ) was recorded in plants of 06 November sowing with high management, which was identical with medium management practices at the same date of sowing. The lowest total dry matter $\left(9 \mathrm{~g} \mathrm{~m}^{-2}\right)$ was recorded at 14 December sowing with low management practices.

Table 3. Accumulated growing degree days $\left({ }^{\circ} \mathrm{C}\right)$ for different developmental events of mustard grown at different sowing dates under different management during rabi season, 2014-2015

\begin{tabular}{|c|c|c|c|c|c|}
\hline \multicolumn{2}{|c|}{ Treatments } & \multicolumn{4}{|c|}{ Developmental events } \\
\hline $\begin{array}{l}\text { Sowing } \\
\text { dates }\end{array}$ & Management & Emergence & First flowering & $\begin{array}{c}50 \% \\
\text { Flowering }\end{array}$ & Maturity \\
\hline
\end{tabular}


Impact of Sowing Date Induced Temperature and Management

\begin{tabular}{llcccc}
\hline 06 Nov. & Low & 89.70 & 591.35 & 665.25 & 1284.35 \\
& Medium & 89.70 & 591.35 & 665.25 & 1323.65 \\
& High & 89.70 & 591.35 & 665.25 & 1323.65 \\
& Low & 95.45 & 475.45 & 564.50 & 1115.90 \\
& Medium & 95.45 & 475.45 & 564.50 & 1172.55 \\
& High & 95.45 & 475.45 & 564.50 & 1172.55 \\
& Low & 72.15 & 476.3 & 521.10 & 1070.20 \\
& Medium & 72.15 & 476.3 & 521.10 & 1154.20 \\
& High & 72.15 & 476.3 & 521.10 & 1154.20 \\
\hline
\end{tabular}

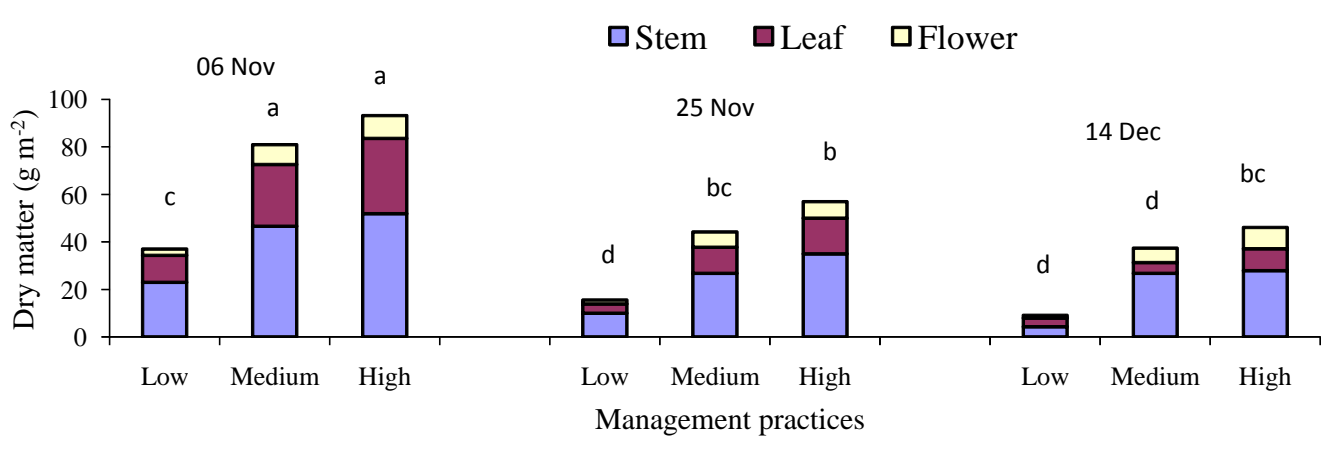

Fig. 2. Dry matter production at flowering and their distribution in different plant parts under different management practices at different sowing dates

Under low management practices the total dry matter produced from 25 November and 14 December sowing was identical. The highest dry matter accumulation in stem $\left(52 \mathrm{~g} \mathrm{~m}^{-2}\right)$, leaf $\left(31.6 \mathrm{~g} \mathrm{~m}^{-2}\right)$ and flower $\left(9.6 \mathrm{~g} \mathrm{~m}^{-2}\right)$ was recorded at 06 November sowing with high management practices and the lowest dry matter in stem $\left(4.4 \mathrm{~g} \mathrm{~m}^{-2}\right)$, leaf $\left(3.6 \mathrm{~g} \mathrm{~m}^{-2}\right)$ and flower $\left(1.2 \mathrm{~g} \mathrm{~m}^{-2}\right)$ at 14 December sowing with low management practice. It might be due to prevailing high temperature at flowering stage that increased photo-respiration and reduced net photosynthesis resulted in lower dry matter production (Sage and Sharkey, 1987). Wellmanaged plants grown at late and high temperature showed higher dry matter production than poor managed one probably due to higher balanced between photorespiration loss and production of photosynthates.

\section{Yield and yield attributes}

Plant populations, plant height, number of branches plant ${ }^{-1}$, number of siliqua plant ${ }^{-1}$, seeds siliqua $^{-1}, 100$-seed weight and seed yield of mustard showed significant difference in different sowing dates and management practices (Table 4). The highest population (70 plant $\mathrm{m}^{-2}$ ) was recorded from 14 December sowing with low management practices and the lowest (52 plant $\mathrm{m}^{-2}$ ) from 06 November sowing with same management practices. The tallest plant was recorded from 06 November sowing with high management practices $(108.20 \mathrm{~cm})$, which was identical with medium management practices at the same date of sowing $(99.50 \mathrm{~cm})$ and high management practices at 25 November sowing $(101.60 \mathrm{~cm})$. The minimum plant was recorded from 14 December sowing with low management practices $(69.93 \mathrm{~cm})$. Significantly the highest number of branches was recorded from 06 November sowing with high management practices $\left(8\right.$ plant $\left.^{-1}\right)$. The lowest branches were recorded at 25 November sowing with low management practices. Sown on 06 November sowing with high management practices also produced the maximum number of siliqua (84 plant $\left.^{-1}\right)$ which was followed by medium management practices at the same date of sowing (70 plant $\left.{ }^{-1}\right)$ and 
Khan et al.

high management practices at 25 November sowing $\left(67\right.$ plant $\left.^{-1}\right)$. The lowest number of siliqua was recorded from 14 December sowing with low management practices (19 plant $^{-1}$ ). High temperature at flowering and siliqua formation stages enhanced flower and siliqua abscissions that reduced the number of siliqua (Sinaki et al., 2007). The maximum reduction in siliqua at 14 December sowing could be due to floral sterility caused by high temperature (Morrison and Stewart, 2002). Seed yield of mustard varied significantly under different sowing dates and management practices. The maximum seed yield also recorded from 06 November sowing with high management $\left(1569 \mathrm{~kg} \mathrm{ha}^{-1}\right)$ which was identical with high management practices at 25 November sowing $\left(1534 \mathrm{~kg} \mathrm{ha}^{-1}\right)$. The lowest seed yield was obtained from 14 December sowing with low management practices (435 kg ha') whereas at high management practices crop yielded $1183 \mathrm{~kg}^{-1}$. High temperature during reproductive phase is a primary constraint to its production. The lower seed yield at 14 December sowing might be due to prevailing high temperature (Fig. 1) during flowering to maturity. The results are in agreement with the findings of Rao et al. (1992). Seed yield reduction of mustard varied from timely sowing to different sowing dates under different management (Table 4).

Table 4. Yield contributing characters and yield of mustard grown at different sowing dates under different management practices during rabi season, 2014-2015

\begin{tabular}{|c|c|c|c|c|c|c|c|c|}
\hline \multicolumn{2}{|c|}{ Treatments } & \multirow{2}{*}{$\begin{array}{l}\text { Plant } \\
\text { population } \\
\left(\mathrm{m}^{-2}\right)\end{array}$} & \multirow{2}{*}{$\begin{array}{l}\text { Plant } \\
\text { height } \\
(\mathrm{cm})\end{array}$} & \multirow{2}{*}{$\begin{array}{c}\text { Branches } \\
\text { plant }^{-1} \\
\text { (no.) }\end{array}$} & \multirow{2}{*}{$\begin{array}{l}\text { Siliqua } \\
\text { plant }^{-1} \\
\text { (no.) }\end{array}$} & \multirow{2}{*}{$\begin{array}{l}\text { Seeds } \\
\text { siliqua }^{-1} \\
\text { (no.) }\end{array}$} & \multirow{2}{*}{$\begin{array}{l}100- \\
\text { seed wt } \\
\text { (g) }\end{array}$} & \multirow{2}{*}{$\begin{array}{l}\text { Seed } \\
\text { yield } \\
(\mathrm{kg} \text { ha } \\
(1)\end{array}$} \\
\hline $\begin{array}{c}\text { Sowing } \\
\text { dates }\end{array}$ & $\begin{array}{l}\text { Manage- } \\
\text { ment }\end{array}$ & & & & & & & \\
\hline \multirow{3}{*}{06 Nov. } & Low & 52 & 77.33 & 3.8 & 26.0 & 19 & 0.29 & 620 \\
\hline & Medium & 56 & 99.50 & 6.4 & 70.0 & 20 & 0.30 & 1245 \\
\hline & High & 52 & 108.2 & 7.8 & 83.8 & 24 & 0.31 & 1569 \\
\hline \multirow[t]{3}{*}{25 Nov. } & Low & 67 & 72.20 & 1.3 & 20.3 & 20 & 0.29 & 583 \\
\hline & Medium & 61 & 94.0 & 5. & 43 & 23 & 0.30 & 1060 \\
\hline & High & 59 & 101.6 & 5.5 & 67.4 & 23 & 0.31 & 1534 \\
\hline \multirow[t]{5}{*}{14 Dec. } & Low & 70 & 69.93 & 2.5 & 18.9 & 18 & 0.29 & 435 \\
\hline & Medium & 61 & 77.40 & 3.9 & 34.3 & 21 & 0.31 & 889 \\
\hline & High & 63 & 83.27 & 4.5 & 55.7 & 21 & 0.31 & 1183 \\
\hline & LSD (0.05) & 6.05 & 10.37 & 0.70 & 13.35 & NS & NS & 155.5 \\
\hline & CV (\%) & 5.68 & 6.69 & 8.62 & 16.07 & 7.90 & 5.31 & 8.63 \\
\hline
\end{tabular}

Seed yield reductions at 14 December sowing compared to 06 November sowing under low, medium and high management practices were 30,29 and $25 \%$, respectively. The seed yield reductions were 72,43 and $25 \%$ under low, medium and high management at 14 December sowing, respectively compared to high management practices at 06 November sowing. Better seed yield in well-managed plants at 14 December sowing could be due to higher accumulation of compatible osmolytes which might helped to increase water retention in plants for better stomata regulation and increased photosynthesis.

\section{Conclusion}

From the above findings, it may be concluded that mustard crop is vulnerable to sowing dates induced temperature variability. Developmental events were badly affected due to late sowing of seeds on 14 December. Yield reduction may be reduced to some extent through 
Impact of Sowing Date Induced Temperature and Management

adopting high management practices. The highest seed yield (1569 $\left.\mathrm{kg} \mathrm{ha}^{-1}\right)$ was recorded from 06 November sowing with high management practices while the lowest seed yield (435 $\mathrm{kg} \mathrm{ha}^{-1}$ ) from 14 December sowing with low management practices. At high management practices the crop yielded $1183 \mathrm{~kg} \mathrm{ha}^{-1}$ at 14 December sowing. Yield reduction at late sowing condition was reduced to some extent with high management practices.

\section{References}

Aggarwal, P. K., 2003. Impact of climate change on Indian agriculture. Plant Biology, 30, pp.189198.

Angadi, S. V., H. W. Cutforth, B. G. McConkey and Y. Gan. 2003. Yield adjustment by canola grown at different plant populations under semiarid conditions. Crop Science. 43: 13581366.

BBS (Bangladesh Bureau of Statistics). 2013. Statistical Yearbook of Bangladesh. Bangladesh Bureau of Statistics, Statistics Division, Ministry of Planning, Govt. People's Republic of Bangladesh.

Cakmak, I. 2002. Plant nutrition research: Priorities to meet human needs for food in sustainable ways. Plant Soil. 247: 3-24.

IPCC, 2007. Climate Change 2007. Impacts, Adaptation and Vulnerability. Working Group II Contribution to Fourth Assessment Report of the Intergovernmental Panel on Climate Change. M.Parry, O.Canziani, J.Palutikof, P.V.D.Linden and C.Hanson, Eds., Cambridge University Presss, Cambridge, pp.1-976.

Kalra, N., P. K. Aggarwal, S. Chander, H. Pathak, R. Choudhary, A. Choudhary, S. Mukesh, H. K. Rai, U. A. Soni, S. Anil, M. Jolly, U. K. Singh, A. Owrs and M. Z. Hussain, 2003. Impacts of climate change on agriculture. Climate Change and India: Vulnerability Assessment and Adaptation. In: Shukla, P. R., S. K. Sharma, N. H. Ravindranath, A. Garg and S. Bhattacharya, Eds., Orient Longman Private Ltd., Hyderabad, pp.193-226.

Kumar, A., V. Pandey, A. M. Shekh and M. Kumar. 2008. Growth and yield response of soybean (Glycine max L.) in relation to temperature, photoperiod and sunshine duration at Anand, Gujarat, India. Am-Euras. J. Agron., 1(2): 45-50.

Morrison, M. J. and D. W. Stewart. 2002. Heat stress during flowering in summer Brassica. Crop Science. 42: 797-803.

Munns, R. 2005. Genes and salt tolerance: bringing them together. Tansley review. New Phytol. 645-656.

Porter, J. R. 2005. Rising temperatures are likely to reduce crop yields. Nature: 436, 174.

Radin , J. W. and M. A. Matthews. 1989. Water transport properties of cortical cells in roots of nitrogen and phosphorus deficient cotton seedlings. Plant Physiol. 89: 264-268.

Rao, G. U., A. Jain and K. T. Shivanna. 1992. Effect of high temperature stress on Brassica pollen: viability, germination and ability to set fruits and seeds. Ann. Bot. 69: 193-198.

Sage, R. F. and T. D. Sharkey. 1987. The effect of temperature on the occurrence of $\mathrm{O}_{2}$ and $\mathrm{CO}_{2}$ insensitive photosynthesis in field grown plants. Plant Physiol. 84: 658-664.

Sinaki, J. M., E. Majidi Heravan, A. H. Shirani Rad, G. Nour Mohammadi and H. Zarei. 2007. The effects of water deficit during growth stages of canola (Brassica napus L.). AmercanEurasian Journal of Agricultural and Environmental Sciences. 2(4): 417-422. 
Khan et al.

Singh, M. P., Lallu and N. B. Singh. 2014. Thermal requirement of Indian mustard (Brassica Juncea) at different phonological stages under late sown condition. Indian J. Plant Physiol. 19(3): 238-243.

Thomas, P. 1984. Canola Growers' Manual. Canola Council of Canada. 301-433. Main St., Winnipeg. Canada.

Waraich, E. A., R. Ahmad, M. Ashraf, Y. Saifullah and M. Ahmad. 2011. Improving agricultural water use efficiency by nutrient management in crop plants. Acta Agriculturae Scandinavica, Section B- Soil \& Plant Sci. 61(4): 291-304 